\title{
Titratable Acids in Opuntia ficus-indica $\mathbf{L}$.
}

\author{
YOCHAI B. SAMISH AND SIGMUND J. ELLERN
}

Highlight: Accumulation of acidity in spiny and spineless Opuntia joints fluctuated daily due to crassulacean acid metabolism (CAM) in Golan Height and coastal plain. The acidity reached higher concentrations in the young joints, especially during early morning hours, before the plants were exposed to sunlight. C'hanges in acidity were more pronounced in the chlorenchyma than in the water-accumulating tissues.

These findings provide information on the rate and time of photosynthesis of these plants and may enable the feeding of livestock on Opuntia, while acid levels taken in by livestock are kept low to reduce a cause of diarrhea. The acidity is lower on sunny warm days, during late afternoons, in shriveled, old joints which had been exposed to full sunlight or were excised and stored in light. It may, therefore, be better to let cattle feed on the shriveled Opuntia before the start of the rainy season and use shrubs such as Atriplex halimus, which is better suited after onset of the first rain, as complementary perennial feed.

The supply of green fodder providing the required vitamins and other nutrients for livestock is often limited temporarily towards the end of the dry season to the grazing of deeprooted leafy shrubs and xerophytes, especially under arid conditions such as those in the Mediterranean climate. Among the xerophytes, which can grow even under extreme conditions, we find cacti, such as the stem succulent Opúntia ficus-indica L. (Fig. 1). In order to cultivate this cactus, Burbank selected a spineless clone. Since Opuntia ficus-indica L. grows readily in all Mediterranean countries, its spineless clone has also been introduced into Israel. Grazing and feeding trials have shown that sheep and cattle eat the modified photosynthesizing stems, called joints (Konis, 1950) or

The a uthors are lecturer, Botany Department, Tel Aviv University, The Dr. George S. Wise Center for Life Sciences; and range scientist, Division of Range Management, Agricultural Research Organization, Volcani Center, Bet Dagan, Israel.

The senior a uthor gratefully acknowledges the interest and help given by Prof. R. M. Samish and Mrs. Zdenka Samish, Dr. N. G. Seligman, the late Prof. N. Tadmor, Prof. Y. Waisel, and Mr. B. Yogev, and especially Mr. R. Yonathan at different stages of his work, as well as the Volcani Center of the Agricultural Research Organization and the "Ambal" Cattle Producers" Organization which made the research possible.

Manuscript received December 30, 1974. slabs, but reacted often with severe diarrhea. Since the joints are rich in acids and acids are known to affect the digestion of cattle, it was suggested that the digestive disturbance after browsing on Opuntia may be due to the high acid content of the feed.

Organic acids are known to accumulate during the metabolism of succulents by crassulacean acid metabolism (CAM), which refers to an increase of titratable acidity in the green tissues at night (dark acidifica- tion) and its reduction in the photosynthesizing tissues during the day (photodeacidification) (Ranson and Thomas, 1960; Milburn et al., 1968) accompanied by an increase of photosynthetic products, particularly adenosine tri-phosphate (ATP). As Pucher et al. (1949) had noted considerable fluctuations in concentration of acids in crassulacean tissue at different hours during the day, it was thought desirable to establish the diurnal cycle of the acid content in Opuntia and the effect of different ecological factors on acidity under local conditions. Thus, it would hopefully become possible to reduce the negative aspects of this feed, by offering it at a time, or under conditions, of rclatively low acid content.

Differences in acid content could be due to changes in the rate of photosynthesis, or to replacement of the CAM metabolism by more common pathways of metabolism (Black, 1973). Such information should be of value in connection with studies towards broadening the utiliza-

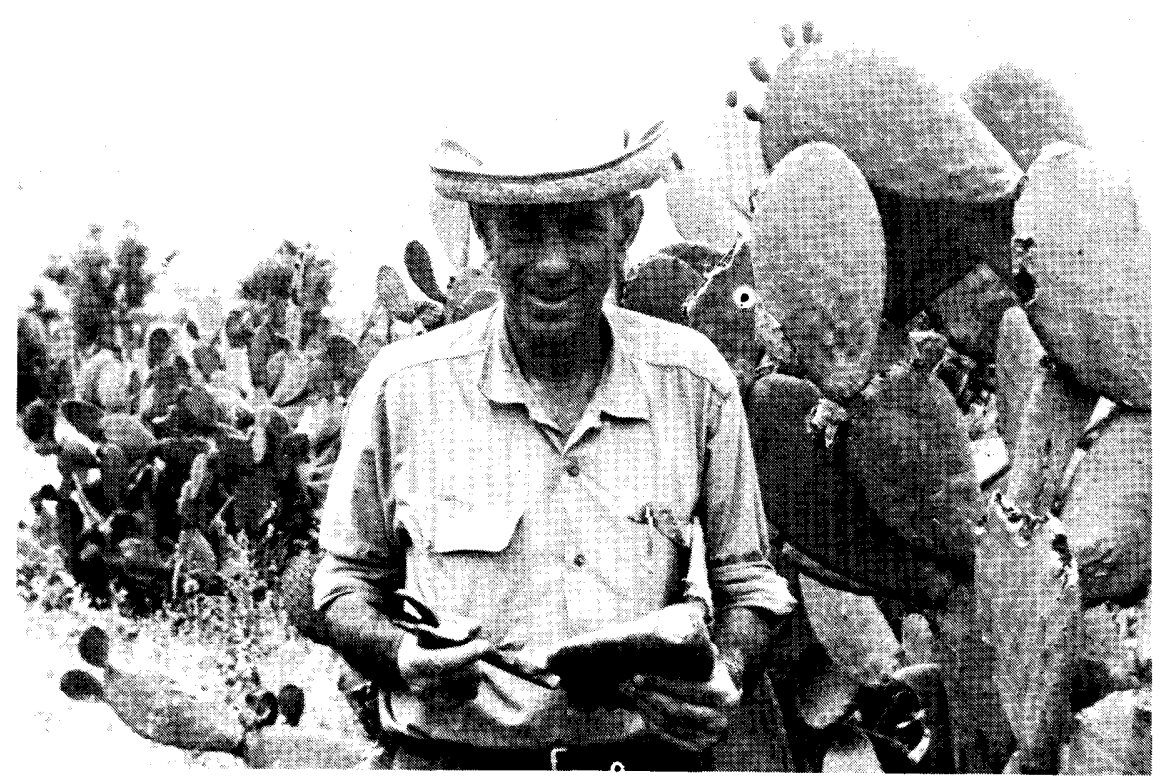

Fig. 1. Photograph of local Opúntia fícus-índica $L$. 


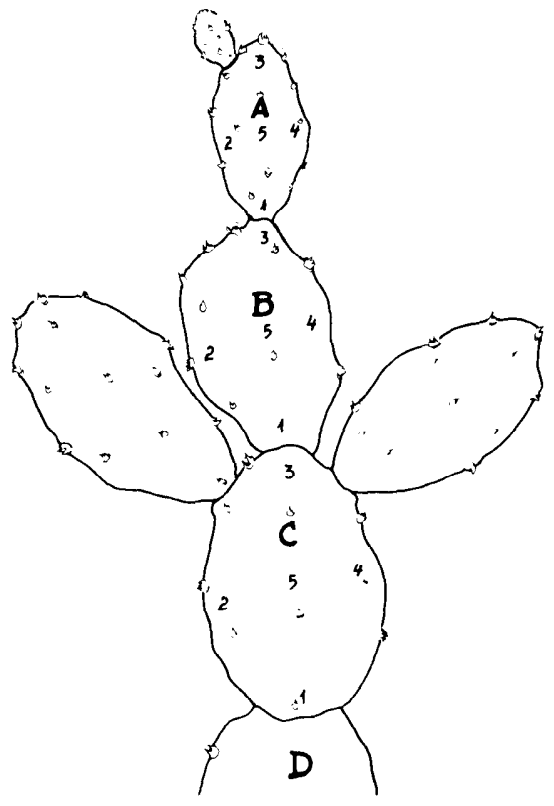

Fig. 2. Location of sampling cores in Opuntia joints of different ages. The youngest joint " $A$ " is about 1 year old and measures $30 \times 16 \mathrm{~cm}$. The joints $B, C$, $D$, and $E$ (not shown) are each about 1 year older than the preceeding one. Five cores, numbered 1-5 were taken from each joint.

tion as well as the understanding of the Opuntia physiology.

\section{Materials and Methods}

The investigation was carried out on two locations: (a) A plantation of spineless cactus at Snir, located at the foot of the Golan Heights, on a slope facing west in shallow, stony, rather meager loam; and (b) hedges of the common, spiny cactus bordering both sides of a trail near Ekron in the central plain, growing in a deep, fertile, black clay loam.

In order to establish the proper sampling procedure, samples were collected from cach of three different plants, using joints of similar age. A cork borer was used to obtain samplecores of $1.6 \mathrm{~cm}^{2}$ cross section, cutting from epidermis to epidermis completely through the joint at five positions: four peripheral equidistal locations, about $2 \mathrm{~cm}$ from the margin, and the fifth in the center of the joint, as indicated in Figure 2. The samples were collected in small bags made of mylar, a plastic material which withstands boiling temperature. The bags were closed and exposed for 20 minutes immediately after sampling in the field to water and steam in order to kill the tissues and to stop enzymatic activity. The samples were not held at low temperature during transport to the laboratory, since it was found that acidity remained the

Table 1. Effect on acid content of relative position and age of Opuntia joints (A is the youngest and $E$ the oldest) and the location of the samples (1 to 5 see Fig. 2) (Snir, Sept. $19698 \mathrm{am})$.

\begin{tabular}{|c|c|c|c|c|c|c|}
\hline \multirow{2}{*}{$\begin{array}{c}\text { Position } \\
\text { and age } \\
\text { of joints }\end{array}$} & \multicolumn{6}{|c|}{ Acids $\mu$ eq per $g$ fresh wt of cores on locations $1-5$} \\
\hline & 1 & 2 & 3 & 4 & 5 & AV. S.E \\
\hline A & 106 & 214 & 167 & 149 & 126 & $152 \pm 42.0$ \\
\hline B & 49 & 56 & 57 & 62 & 56 & $56 \div 5.0$ \\
\hline $\mathrm{C}$ & 55 & 47 & 52 & 40 & 44 & $48 \pm 5.8$ \\
\hline D & 39 & 59 & 51 & 64 & 40 & $52 \pm 10.8$ \\
\hline $\mathrm{E}$ & 40 & 16 & 37 & 38 & 40 & $34 \pm 10.2$ \\
\hline Averages & 58 & 78 & 72 & 70 & 62 & $68 \pm 14.8$ \\
\hline
\end{tabular}

same whether the heated samples had been stored for 48 hours in cold storage or at ambient temperatures. In the laboratory, the samples, each consisting of 5 cores, were weighed, homogenized in a Waring Blender, made up to a standard volume, and stored at $4{ }^{\circ} \mathrm{C}$ until analysis. Aliquots were titrated with $0.02 \mathrm{~N} \mathrm{NaOH}$, using phenolphthalein as indicator and the results rcported as number of equivalents.

Results were calculated on a fresh weight and per core basis. Calculating on either per core basis (i.e., area of joint) or on basis of fresh weight, deviations from average, when referred to the average titer, were not consistent between methods of calculation (Table 5). From the two comparisons discussed above, either could be chosen for reporting the results; we found that per core comparison is a simple parameter to use during field measurements.

\section{Results}

Table 1 shows the extent to which acidity is affected by the position of the joint along the stem, designated basipetally along the axis, with " $A$ " for the youngest terminal joint to " $E$ " for the oldest one (see Fig. 2).

Comparing the acidity of the joints according to age, we note that their titratable acidity decreased significantly according to their basipetal position (in the morning) with increasing age. This is presumably due to the relatively higher accumulation of carbohydrates during the previous day and the higher rate of metabolism (dark-acidification during the preceeding night) of younger tissues with a larger proportion of chlorenchyma. A contributing natural factor may have been the shading of the lower joints, causing their slower photodeacidification.

Furthermore, it was established that the older leaves contain a larger proportion of water accumulation tissue, which would be expected to be metabolically less active than the outer chlorenchyma. As to the position of the samples on the joints, we found a rather insignificant small increase of acidity near the periphery, as compared with the center of the joints. On the basis of these results, we used in our further study only young joints of similar age, compounding the cores from all five locations, and selected nonshaded joints. In those cases when the morning sampling could not be continued during the afternoon, in the remote field at Snir, data of the previous afternoon have been used to give the daily change.

Typical curves for the change in acidity of the Opuntia joints during daylight hours are illustrated in Figure 3. The curve calculated on fresh weight basis as well as that reported per core (i.e., relative to unit area) show a continuous loss of acidity during daylight hours, typical for CAM.

The early fluctuations on fresh weight basis may possibly be due to the absorption of water and/or slight differences in turgidity among differ-

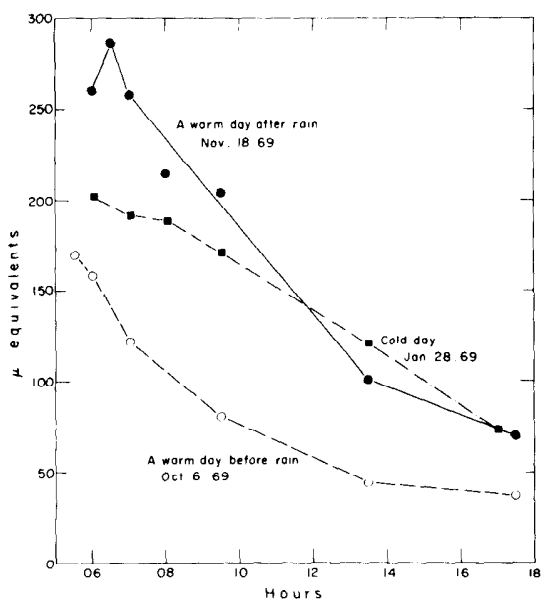

Fig. 3. Diurnal changes of acidity per core in spineless Opuntia joints at Snir on cold and warm days. 
Table 2. Excess acidity ( $\mu$ equivalents) in turgid young joints at position "A" (Fig. 2) in Oct., 1970, as compared with shriveled joints growing on shallow dry soil.

\begin{tabular}{cccc}
\hline \hline & & \multicolumn{2}{c}{$\begin{array}{c}\text { Excess acidity in } \\
\text { turgid as compared } \\
\text { to shriveled joints }\end{array}$} \\
\cline { 2 - 4 } $\begin{array}{c}\text { Hour } \\
\text { of } \\
\text { sampling }\end{array}$ & $\begin{array}{c}\text { Acidity per } \\
\text { g shriveled } \\
\text { joint }\end{array}$ & $\begin{array}{c}\text { Per } \\
\text { core }\end{array}$ & $\begin{array}{c}\text { Per } \\
\text { gram }\end{array}$ \\
\hline 6 & $160 \pm 16$ & $126 \pm 40$ & $56 \pm 18$ \\
14 & $36 \pm 4$ & $26 \pm 14$ & 0 \\
\hline
\end{tabular}

ent slabs.

The acidity of the common spiny Opuntia at Ekron showed changes in the course of the day similar to the spineless one at Snir. At Ekron we analyzed samples from hedges lining both sides of a trail running north to south and shading one another when the sun stood low. The hedge on the west side received full sunlight merely during the afternoon, while that of the cast side received more sunlight during the morning. The daily acidity cycle was affected by the shade, as shown in Figure 4. Photo-deacidification started in the eastern side with sunrise, but was delayed in the western side until mid-morning.

The effect of climatic conditions was considered and the results were compared with the meteorological data provided in Table 3 . The individual effect of meteorological data in the open is not easy to evaluate, especially since different factors are often interrelated, such as the frequent association of rain with a reduction in temperature and sunlight. Air temperature may not exactly correlate with the temperature of the insolated organ, which is likely to be raised considerably above air temperature by solar irradiation, particularly in Opuntia (Konis, 1950). Thus in addition to air temperature the intensity of solar radiation may be taken into account.

The effect of soil moisture is illustrated in Figure 3 and Tables 2 and 4; at the end of the dry season no rain has as yet fallen before October 6 . After this date and before November $16,69 \mathrm{~mm}$ of rain precipitated. On those two dates, before and after the rain, the two curves show deacidification. But during the night before sampling in November, acidity reached a far higher value, due possibly to improved metabolic conditions as a result of sufficient moisture supply. A
Table 3. Meteorological data at Snir Area. Scale for cloudiness from 0 to full sky cover marked as 8 (e.g., $1 / 2$ sky cover is noted as 4 ), minimal, maximal, and average temperatures in ${ }^{\circ} \mathrm{C}$.

\begin{tabular}{|c|c|c|c|c|c|c|c|c|c|}
\hline \multirow[b]{3}{*}{ Date } & \multirow{3}{*}{$\begin{array}{c}\text { Rainfall } \\
\text { during } 30 \\
\text { days before } \\
\text { sampling } \\
\text { (mm) }\end{array}$} & \multicolumn{6}{|c|}{ Weather during 24 hours before sampling } & \multirow{3}{*}{$\begin{array}{c}\text { Sun } \\
\text { rise } \\
\text { (hour) }\end{array}$} & \multirow{3}{*}{$\begin{array}{c}\text { Sun } \\
\text { set } \\
\text { (hour) }\end{array}$} \\
\hline & & \multicolumn{3}{|c|}{ Temperature $\left({ }^{\circ} \mathrm{C}\right)$} & \multicolumn{3}{|c|}{ Cloudiness } & & \\
\hline & & Min & $\operatorname{Max}$ & Avg & $8 \mathrm{am}$ & $14 \mathrm{pm}$ & $20 \mathrm{pm}$ & & \\
\hline \multicolumn{10}{|l|}{1969} \\
\hline Oct. 4 & 0 & 17 & 31 & 23.5 & 0 & 0 & 0 & & \\
\hline Oct. 5 & 0 & 19 & 32 & 25.0 & 6 & 6 & 8 & $5: 13$ & $17: 20$ \\
\hline Oct. 6 & 0 & 19 & 35 & 27.1 & 5 & 4 & 8 & & \\
\hline \multicolumn{10}{|l|}{1969} \\
\hline Nov. 16 & 69 & 10 & 28 & 18.8 & 0 & 0 & 0 & & \\
\hline Nov. 17 & 69 & 9 & 28 & 18.0 & 0 & 0 & 0 & $6: 10$ & $16: 40$ \\
\hline Nov. 18 & 69 & 9 & 28 & 18.0 & 0 & 0 & 0 & & \\
\hline \multicolumn{10}{|l|}{1970} \\
\hline Jan. 26 & 168 & 7 & 15 & 10.8 & 0 & 0 & 0 & & \\
\hline Jan. 27 & 168 & 4 & 15 & 9.0 & 6 & 2 & 0 & $6: 38$ & $17: 09$ \\
\hline Jan. 28 & 168 & 4 & 6 & 9.5 & 0 & 2 & 0 & & \\
\hline \multicolumn{10}{|l|}{1970} \\
\hline Oct. 11 & 21 & 14 & 29 & 21.0 & 0 & 4 & 0 & & \\
\hline Oct. 12 & 21 & 15 & 28 & 21.0 & 3 & 5 & 2 & $5: 41$ & $17: 13$ \\
\hline $\begin{array}{l}\text { Oct. } 13 \\
1971\end{array}$ & 21 & 12 & 21 & 16.0 & 7 & 3 & 4 & & \\
\hline Feb. 17 & 35 & - & - & - & 3 & 0 & 0 & $6: 22$ & $17: 27$ \\
\hline Feb. 18 & 35 & 9 & 23 & 16.0 & 0 & 0 & 0 & & \\
\hline
\end{tabular}

higher acidity level was retained during the day, due to the higher start in the morning, as compared with the plants which were sampled earlier in October, Comparison of shriveled Opuntia growing on shallow dry soil with ones on deep soil (Table 2) at the same time provided a double check of the soil moisture effect. Low night temperature seems to favor higher acidity on the following day. Minimum temperature was below $10^{\circ} \mathrm{C}$ on November $16-17$ as against $19^{\circ} \mathrm{C}$ on October 6.

On the hot days of November 16-18, with an average temperature of $18^{\circ} \mathrm{C}$ and a minimum temperature as low as $9^{\circ} \mathrm{C}$, the early morning samples showed a very high acidity (Fig. 3 and Table 3) with a titer of about $285 \mu$ eq (microequivalents) per core; and this maximum acidity was obtained at 6:30 a.m. (i.e., about 20 minutes after sunrise), with a low titer of only $70 \mu$ eq in the late afternoon. Thus, high day temperatures seem to favor Opuntia CAM processes, so that a high maximum and a low minimum acidity (i.e., at the end of the dry season). are reached in periods of hot days and cold nights. On the other hand, on October 6 (Fig. 3) low morning acidity of $166 \mu$ eq was obtained during a dry period of also very warm days with daily average temperatures reaching up to $25^{\circ} \mathrm{C}$ and a minimum of between 17 and $19^{\circ} \mathrm{C}$. Under these conditions minimum acidity remained low $(38 \mu$ eq) in the afternoon, but no strong acidification seems to have taken place during the warm night. Thus the rate of CAM photosynthesis must have

Comparing cloud cover during these two days we find it was high during the beginning of October, which may have reduced the accumulation of carbohydrates; the cloudless sky during November $16-18$ is likely to have increased temperature of the joints far above the recorded air temperature in the course of the day, which may have enhanced the deacidification and the accumulation of carbohydrate accordingly.

Calculating the daily mid value for the acidity of a number of such curves, we find a wide range, the mid value been low.

Table 4. Thickness ( $\mathrm{mm}$ ) of young joints at Snir at the end of the dry season (October) and at the end of the rainy season (February) by turgidity (i.e., water availability) class.

\begin{tabular}{lcccr}
\hline $\begin{array}{l}\text { Turgidity and } \\
\text { sampling date }\end{array}$ & $\begin{array}{c}\text { No. of } \\
\text { joints } \\
\text { measured }\end{array}$ & $\begin{array}{c}\text { Chlorenchyma } \\
\text { (green) }\end{array}$ & $\begin{array}{c}\text { Water- } \\
\text { accumulating } \\
\text { tissue }\end{array}$ & $\begin{array}{c}\text { Whole } \\
\text { joints }\end{array}$ \\
\hline Turgid - Oct. 8 & 18 & $2.4 \pm 0.5$ & $4.3 \pm 1.1$ & $6.7 \pm 1.0$ \\
Shriveled - Oct. 8 & 9 & $1.3 \pm 0.4$ & $1.0 \pm 0.3$ & $2.3 \pm 0.4$ \\
Very turgid - Feb. 21 & 24 & $3.0 \pm 1.2$ & $9.0 \pm 1.2$ & $12.0 \pm 1.2$ \\
\hline
\end{tabular}




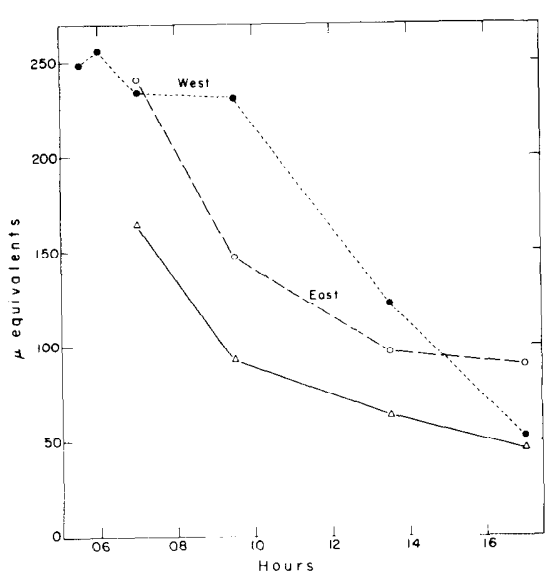

Fig. 4. Differences in acidity per core between the eastern side (O) and the western side (๑) of spiny Opuntia along hedges in Ekron. The eastern side data of Oct. 29, 1969 , are also given per gram fresh weight $(\Delta)$.

being reached as early as 8 a.m. on October 6, 1969 (Fig. 3), but only just before noon, on November 18, 1969. Corresponding to a relatively stccp drop on the morning of October 6, the curve consequently flattened out rather early at noon, while on November 18 the decline. of acidity was not quite as steep in the morning. The rapid decline on October 6 would seem to be due to the relatively high temperature on that date, while the gradual drop in January is associated with a lower temperature. This effect would agree with our knowledge concerning rate of photosynthesis, which is associated with photodeacidification at daytime.

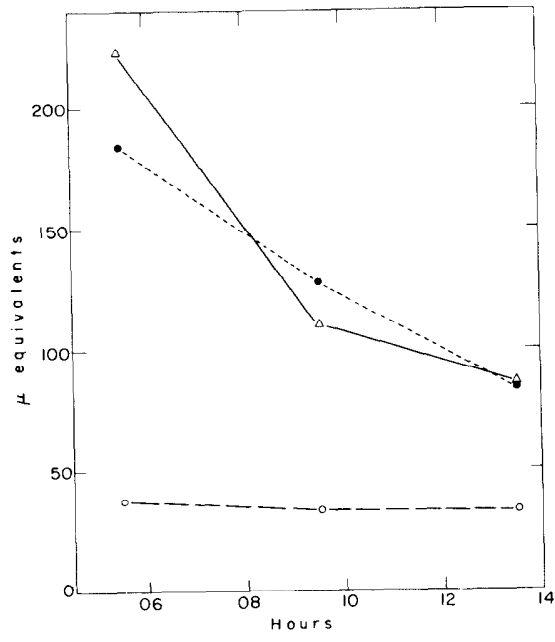

Fig. 5. The acidity in the wateraccumulating tissue (per gram o), and in the chlorenchyma (per gram $\triangle$ and per core $\bullet$; of spineless Opuntia at Snir on October 13, 1970.
It was thought interesting to compare the behaviour of the two major tissue groups into which the core can be easily separated-the outer chlorenchyma and the inner wateraccumulating spongy part. The behaviour with respect to acidity is illustrated in Figure 5. It is seen that the amount of acid per unit core is throughout much higher in the morning in the chlorenchyma $(220 \mu \mathrm{eq} / \mathrm{g})$, than in the pulp, with a corresponding $37 \mu$ eq/g remaining low and rather constant throughout the day. Considering this, it would be expected that practically all the photosynthesis of the core is located in the chlorenchyma. The ratio between the two tissues is greatly affected by water supply, as shown in Table 4, which compares quite turgid plants at the end of the dry season, growing in relatively deep soil, with those of wilted plants growing nearby in shallow soil underlain by rocks. As would be expected, the wateraccumulating inner tissue collapsed and is much more affected by the drought than the chlorenchyma, reducing the thickness of the inner layer to about one-forth, while the outer chlorenchyma was reduced in thickness to only a smaller extent.

The main accumulating acid is malic acid. Considerations of efficient cutting may make it desirable to cut and store the joints before feeding. The effect of length of storage under different conditions of insolation is shown in Table 5.

When the cut joints were exposed to light by spreading them, the reduction of acidity continued, although at a lesser rate than on the plant. By spreading the joints in the sunlight, only one of the two photosynthetic surfaces was exposed to light, which may explain the reduced rate of pho- todeacidification as compared to joints on the plant. When they were stored in the dark by piling them into a heap and covering with black nylon, acidity increased; i.e., CAM metabolism was continued after the joints were severed from the plant.

\section{Discussion}

Measurements of the changes in titrable acidity of joints of Opuntia showed that CAM dominates the photosynthetic metabolism of this plant in Israel. We found a build-up of acids in the plant at night and a decrease of acidity during daylight hours. The rate of these changes was affected by ecological conditions: shade decreased the rate of photodeacidification and darkness even stopped it completely.

The relative level of acidity under our conditions would seem to be affected more by the level of acidity reached during the night before than by conditions during the subsequent day. Regardless of early morning acidity levels, by late afternoon acidity consistently dropped to less than 100 $\mu$ eq.

While our field observations are likely to be of some interest to the botanist, they were primarily designed to solve a problem in livestock nutrition. The information obtained still needs to be verified by feeding experiments. Assuming that the acidity, as found in the young joints, is detrimental to ruminants, it remains to determine the amount of acidity which causes indigestion. Since the level of acidity differs so widely during the day, it may be possible that acidity is reduced during the day sufficiently.

Recourse might also be taken to the difference in acidity between the comparatively higher acid content of new and old growth; the terminal young

Table 5. Titratable acids ( $\mu$ equivalents) in detached joints from Snir Feb. 18, 1971 as affected by light during storage. The results were obtained from compound samples of 5 cores from each of 6-8 joints.

\begin{tabular}{lcccc}
\hline Storage treatment & $\begin{array}{c}\text { Hour of } \\
\text { sampling }\end{array}$ & $\begin{array}{c}\text { Acidity } \\
\text { per core }\end{array}$ & $\begin{array}{c}\text { Acidity } \\
\text { per gram } \\
\text { fresh weight }\end{array}$ & pH \\
\hline Freshly harvested control & 9 & $112 \pm 22$ & - & 4.58 \\
& 17 & $56 \pm 6$ & - & 5.09 \\
Stored 4 days in dark ness & 9 & $132 \pm 4$ & $52 \pm 6$ & 4.70 \\
& 15 & $152 \pm 26$ & $50 \pm 6$ & 4.64 \\
Stored in 36 hours in natural light & 9 & $138 \pm 36$ & $52 \pm 6$ & 4.68 \\
Stored 4 days in natural light & 9 & $154 \pm 16$ & $52 \pm 4$ & 4.65 \\
& 15 & $78 \pm 4$ & $30 \pm 2$ & 4.90 \\
\hline
\end{tabular}


new growth might be removed before browsing, leaving only the older joints with their lower acidity. All these measures may be undertaken. However, one has to bear in mind that the incidence of rain would seem to have increased acidity. Szarek and Ting (1974) support some of our findings in their work on Opuntia basilaris.

Since Opuntia joints contain a sufficient store of water in the inner tissues, which are specialized for this purpose, it can be classified as fresh fodder even after storage for several days. However, when joints were stored in the dark after being severed from the plant, acid concentration rose, but when they were exposed to the sun, a partial destruction of the acids occurred during each day, reducing the acidity of the feed.

It is hoped that our results will encourage further experiments which may help to supply arid zones with an additional fodder for their animal husbandry.

\section{Summary}

Acidity in Opuntia, which may affect grazing animals unfavourably, was found in Israel to be highest in the young joints (modified leaves) especially in their green chlorenchyma.

Titrable acids were higher during the early morning hours before daylight, which is indicative for crassulacean acid metabolism (CAM).

When the plants were exposed to light for several hours in nature in the field or abscized joints exposed to light during storage, the (daily) concentration in titrable acidity level declined sharply during the afternoon. Turgid plants were of higher acidity during the morning hours than drought-shriveled ones.

Spineless Opuntia behave similarly to the spiny type. The diarrhea of cattle reported by rangers may be due to grazing on fresh young Opuntia, especially in the early cool morning hours. This harmful effect could possibly be reduced or avoided by limiting grazing to afternoon hours, preferably before the start of the rainy season, i.e., when the joints are still relatively shriveled, and the nights are warm.

\section{Literature Cited}

Black, C. C. 1973. Photosynthetic carbor fixation in relation to net $\mathrm{CO}_{2}$ uptake Ann. Rev. Plant Physiol. 24:253-286.

Konis, E. 1950. On the temperature of Opuntia joints. Pal. J. Bot., J. Series 5:46-55.

Milburn, R. T., D. J. Pearson, and N. A Ndegwe. 1968. Crassulacean acid metab olism under natural tropical conditions New Phytol. 67:883-897.

Pucher, G. W., H. B. Vickery, M. D Abrahams, and C. S. Leavenworth. 1949 Studies in the metabolism of cras sulacean plants: diurnal variation o organic acids and starch in excised leave: of Bryophyllum calycinum. Plan Physiol. 24:610-620.

Ranson, S. L., and M. Thomas. 1960 Crassulacean acid metabolism. Ann. Rev Plant Physiol. 11:81-110.

Szarek, S. R., and I. P. Ting. 1974. Scasona patterns of acid metabolism and ga exchange in Opuntia basilaris. Plan Physiol. 54:76-81.

Toledano, D., and J. Katznelson. 1972. Call feeding by spineless Opuntia (ir Hebrew). Hassadeh 52:600-601. 